\title{
Evaluation of second-trimester maternal serum betatrophin levels and lipid and carbohydrate metabolism parameters in patients with gestational diabetes mellitus
}

\section{Gestasyonel diabetes mellituslu hastalarda ikinci trimester maternal serum betatropin düzeyleri ve lipid ve karbonhidrat metabolizması parametrelerinin değerlendirilmesi}

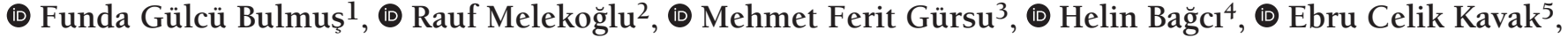 \\ (D) Alpaslan Akyol ${ }^{6}$
}

${ }^{1}$ Firat University Faculty of Medicine, Vocational School of Health Services, Elazı̆̆, Turkey

2Inönü University Faculty of Medicine, Department of Obstetrics and Gynecology, Malatya, Turkey

3 Firat University Faculty of Medicine, Department of Biochemistry, Elazığ, Turkey

${ }^{4}$ Karabük University Training and Research Hospital, Clinic of Obstetrics and Gynecology, Karabük, Turkey

${ }^{5}$ Furat University Faculty of Medicine, Department of Obstetrics and Gynecology, Elazı̆̆, Turkey

${ }^{6}$ Furat University Faculty of Medicine, Department of Obstetrics and Gynecology, Elazı̆̆, Turkey

\begin{abstract}
Objective: We investigated the role of betatrophin in the etiopathogenesis of gestational diabetes mellitus (GDM) and its association with lipid and carbohydrate metabolism in patients with GDM and normoglycemic pregnant women.

Materials and Methods: A total of 60 patients [30 pregnant women with GDM (study group) and 30 healthy age-, body mass index-, and gestational agematched pregnant women (control group)] were included in this study. Serum betatrophin, fasting glucose, insulin, glycated hemoglobin Alc (HbAlc), and C-peptide levels, as well as lipid parameters, were measured.

Results: Serum betatrophin, fasting glucose, $\mathrm{HbAlc}$, insulin, and C-peptide levels were significantly higher in the GDM group than in the control group $(\mathrm{p}<0.001, \mathrm{p}=0.009, \mathrm{p}=0.013, \mathrm{p}<0.001$, and $\mathrm{p}<0.001$, respectively). Levels of triglycerides and very-low-density lipoprotein cholesterol were significantly higher in the GDM group ( $\mathrm{p}=0.020$ and $\mathrm{p}=0.020$, respectively), but total cholesterol and LDL cholesterol levels were similar in the two groups ( $\mathrm{p}=0.810$ and $\mathrm{p}=0.273$, respectively). Betatrophin levels in the GDM group were correlated positively with insulin levels $(\mathrm{r}=0.336, \mathrm{p}=0.009)$ and the homeostatic model assessment of insulin resistance (HOMA-IR) score ( $\mathrm{r}=0.269, \mathrm{p}=0.038)$, and negatively with the C-peptide levels $(\mathrm{r}=-0.399$, $\mathrm{p}=0.002)$; they were not correlated with any other glucose or lipid parameters. Multivariate stepwise linear regression analysis demonstrated that insulin levels $(\beta=0.134$, $p=0.013)$ and the HOMA-IR score $(\beta=0.112, \mathrm{p}=0.017)$ were associated independently with serum betatrophin levels.

Conclusion: These results demonstrate that serum betatrophin levels were significantly higher in pregnant women with GDM than in normoglycemic pregnant women. The levels of betatrophin were correlated significantly with insulin resistance parameters, which is a key feature of GDM pathophysiology. Keywords: Betatrophin, gestational diabetes mellitus, insulin resistance
\end{abstract}

PRECIS: In this study, we compared serum levels of betatrophin in women with and without gestational diabetes mellitus, and investigated the relationships between betatrophin and lipid and glucose metabolism parameters.

Address for Correspondence/Yazışma Adresi: Rauf Melekoğlu, MD,

İnönü University Faculty of Medicine, Department of Obstetrics and Gynecology, Malatya, Turkey

Phone: +90 5066166023 E-mail: rmelekoglu@gmail.com ORCID ID: orcid.org/0000-0001-7113-6691

Received/Geliș Tarihi: 11.11.2019 Accepted/Kabul Tarihi: 29.02.2020

${ }^{\oplus}$ Copyright 2020 by Turkish Society of Obstetrics and Gynecology

Turkish Journal of Obstetrics and Gynecology published by Galenos Publishing House 


\section{$\ddot{\mathrm{O} z}$}

Amaç: Bu çalışmada betatropinin gestasyonel diabetes mellitus (GDM) etiyopatogenezindeki rolünü ve GDM ile komplike ve normoglisemik gebe kadınlarda betatropinin lipid ve karbonhidrat metabolizması ile ilişkisini araştırdık.

Gereç ve Yöntemler: Çalışmaya toplam 60 hasta [GDM tanısı konmuş 30 gebe (çalışma grubu) ve 30 sağlıklı yaş, vücut kitle indeksi- ve gebelik haftası eşleştirilmiş gebe (kontrol grubu)] alındı. Serum betatropin, açlık glukozu, insülin, glikolize hemoglobin Alc (HbAlc), C-peptid düzeyleri ve lipid parametreleri ölçüldü.

Bulgular: Serum betatropin, açlık glukozu, HbAlc, insülin ve C-peptid düzeyleri GDM grubunda kontrol grubundan anlamlı olarak daha yüksekti (sirasıly; $\mathrm{p}<0,001, \mathrm{p}=0,009, \mathrm{p}=0,013, \mathrm{p}<0,001$ ve $\mathrm{p}<0,001)$. GDM grubundaki betatropin düzeyleri ile insülin seviyeleri $(\mathrm{r}=0,336, \mathrm{p}=0,009)$ ve insülin direnci homeostatik model değerlendirmesi (HOMA-IR) skorunun $(r=0,269, p=0,038)$ pozitif ve $C$-peptid seviyesi ile negatif olarak korelasyon gösterdiği bulundu ( $\mathrm{r}=-0.399, \mathrm{p}=0,002)$. Bununla birlikte betatropinin diğer glukoz veya lipid parametreleri ile korele olmadığı saptandı. Çok değişkenli kademeli doğrusal regresyon analizi, insülin seviyelerinin $(\beta=0,134, \mathrm{p}=0,013)$ ve HOMA-IR skorunun $(\beta=0,112, \mathrm{p}=0,017)$ serum betatropin seviyeleri ile bağımsız olarak ilişkili olduğunu gösterdi.

Sonuç: Bu sonuçlar GDM'li gebelerde serum betatropin düzeylerinin normoglisemik gebelere göre anlamlı derecede yüksek olduğunu göstermektedir. Betatropin seviyeleri, GDM patofizyolojisinin kilit bir özelliği olan insülin direnci parametreleri ile anlamlı şekilde korele idi.

Anahtar Kelimeler: Betatropin, gestasyonel diabetes mellitus, insülin direnci

\section{Introduction}

Gestational diabetes mellitus (GDM) is defined as impaired carbohydrate tolerance characterized by severe hyperglycaemia that is recognized for the first time during pregnancy ${ }^{(1)}$. GDM affects approximately $7 \%$ of all pregnancies; the rate varies from 1-28\% depending on the diagnostic criteria and the study population ${ }^{(2)}$. GDM is associated with increased maternal, foetal, and neonatal risks, including preterm birth, hypertensive disease of pregnancy, macrosomia, polyhydramnios, foetal death, operative delivery, caesarean delivery, birth trauma, hypoglycaemia, hyperbilirubinemia, and respiratory distress syndrome $^{(3)}$. GDM treatment is associated with significant reductions in primary outcomes from severe complications, such as perinatal death, shoulder dystocia, birth trauma, macrosomia, and preeclampsia( ${ }^{(4)}$. Thus, screening for GDM is recommended for all pregnant women at 24-28 weeks' gestation, using a laboratory-based screening test and blood glucose levels when the diabetogenic effects of pregnancy are evident ${ }^{(5)}$.

Betatrophin is a recently identified circulating endocrine hormone that is secreted primarily by the liver and adipose tissue and plays an essential role in glucose homeostasis by promoting beta-cell proliferation ${ }^{(6)}$. This hormone, also known as lipasin, hepatocellular carcinoma-associated protein TD26, angiopoietin-like protein 8 , and refeeding-induced fat and liver protein, also plays an important role in lipid metabolism by inhibiting lipoprotein lipase and reducing triglyceride clearance $^{(7)}$. Studies have demonstrated that the expression of betatrophin is induced by insulin, food intake, and cold exposure, but is suppressed by starvation ${ }^{(8,9)}$. Some researchers noted that overexpression of betatrophin improved glucose tolerance by promoting $\beta$-cell proliferation and insulin production, whereas others failed to find any association between the expression of betatrophin and $\beta$-cell growth ${ }^{(10,11)}$. Increasing evidence suggests an association between altered betatrophin levels and type 2 DM or obesity, but the correlation between betatrophin expression and GDM is controversial. In addition, the effect of the betatrophin level on glucose and lipid metabolism has been controversial in several studies. Therefore, in this study, we compared serum levels of betatrophin in women with and without GDM, and investigated the relationships between betatrophin and lipid and glucose metabolism.

\section{Materials and Methods}

This study was approved by the Local Ethics Committee of Firat University, and informed consent was obtained from all participants in accordance with the principles of the Declaration of Helsinki (approval no: 97132852/050.01.04). Sixty participants [30 pregnant women with GDM (study group) and 30 healthy age-, gestational age- and body mass index (BMI)-matched pregnant women (control group)] were enrolled in this prospective case-control study from the Frrat University Faculty of Medicine, Department of Obstetrics and Gynaecology between January 2017 and January 2018.

The inclusion criteria were maternal age 18-39 years, viable singleton pregnancy, admission for GDM screening at 24-28 weeks' gestation, $\mathrm{BMI}<35 \mathrm{~kg} / \mathrm{m}^{2}$, and an unremarkable medical or obstetric history. Exclusion criteria were the presence of any congenital malformation or chromosomal abnormality, foetal death, multiple pregnancies, maternal polycystic ovary syndrome, pregestational DM, family history of DM in a firstdegree relative, hypertensive disease during pregnancy, chronic maternal disease (chronic hypertension, dyslipidaemia, chronic renal failure, pulmonary or cardiac disease, and malignancy), the use of any medication that interferes with lipid or glucose metabolism, and smoking or alcohol consumption. Gestational age was determined from the first day of the last menstrual period and confirmed by first trimester or early secondtrimester ultrasonography.

GDM screening was performed in all participants between 24 and 28 gestational weeks using the 75-g oral glucose tolerance test (OGTT), as defined by the International Association of Diabetes and Pregnancy Study group one-step diagnostic approach $^{(12)}$. After fasting for 8-10 h, the patients were requested to drink $75 \mathrm{~g}$ anhydrous glucose dissolved in $300 \mathrm{~mL}$ water within $5 \mathrm{~min}$, followed by a measurement of venous plasma glucose concentrations 1 and $2 \mathrm{~h}$ after ingestion. The diagnosis of GDM was based on a single serum glucose level that met or exceeded the cut-off values (fasting glucose, $92 \mathrm{mg} / \mathrm{dL} ; 1 \mathrm{~h}$ 
value, $180 \mathrm{mg} / \mathrm{dL} ; 2 \mathrm{~h}$ value, $153 \mathrm{mg} / \mathrm{dL}$ ). Blood samples were centrifuged at $3500 \mathrm{rpm}$ for $5 \mathrm{~min}$ to separate sera. Fasting plasma glucose levels and fasting serum levels of insulin and C-peptide were used to evaluate pancreatic $\beta$-cell function; we also measured serum levels of lipid metabolism parameters [total cholesterol; low-density-lipoprotein (LDL), highdensity-lipoprotein (HDL), and very-low-density-lipoprotein (VLDL) cholesterol; and triglycerides]. Betatrophin levels and other biochemical parameters were measured on the day of OGTT screening. Glucose, lipid, and glycated hemoglobin Alc (HbAlc) levels were analyzed on an Olympus AU 2700 autoanalyzer (Olympus Optical Co., Tokyo, Japan). The homeostatic model assessment of insulin resistance (HOMAIR) score, calculated by the formula defined by Matthews et al. ${ }^{(13)}$, was used to measure insulin resistance [fasting insulin level $(\mu \mathrm{U} / \mathrm{mL}) \times$ fasting glucose level $(\mathrm{mmol} / \mathrm{L}) / 22.5]$. BMI was measured during OGTT screening using the calculation: weight (kg)/height $(\mathrm{m})^{2}$.

Serum levels of betatrophin were determined using an enzyme-linked immunosorbent assay (ELISA; catalogue no. E-EL-H2206; Elabscience, Houston, TX, USA). Absorbance at $450 \mathrm{~nm}$ was recorded using an ELX800 ELISA reader. An automated model ELX50 washer was used to wash the plates. The assay results are expressed in $\mathrm{pg} / \mathrm{mL}$ (range: $125-800 \mathrm{pg} /$ $\mathrm{mL})$.

\section{Statistical Analysis}

A power analysis (PASS 11; NCSS, LLC, Kaysville, UT, USA; www.ncss.com) suggested that at least 29 subjects should be included in each group if the greatest between-group difference in the betatrophin level was $11.12 \mathrm{ng} / \mathrm{mL}$, with a standard deviation (SD) of $4.3 \mathrm{ng} / \mathrm{mL}$, type I error of 0.05 , and type II error of $0.10^{(14)}$. We recorded age, gravidity, parity, BMI, gestational age at screening, and perinatal outcomes of the patient and control groups. The Statistical Package for the Social Sciences version 22.0 software (SPSS Inc., Chicago, IL, USA) was used for the data analysis. Data are reported as means \pm SDs, medians (ranges), or percentages. The normality of data distribution was checked using the Shapiro-Wilk test. Student's t-test was employed to compare biochemical parameters between the control and study groups. The Mann-Whitney U test was used to compare data when dependent variables were not normally distributed. The chi-square test and Fisher's exact test were used to compare categorical variables between the groups, as appropriate. Univariate correlations were analyzed using a nonparametric Spearman's correlation test. Multivariate stepwise linear regression was used to detect independent relationships between the metabolic parameters and serum betatrophin levels. p values $<0.05$ were considered to be significant.

\section{Results}

The maternal characteristics and perinatal outcomes of the study and control groups are summarized in Table 1. Patients were matched in terms of age, BMI, and gestational age at screening, and these parameters did not differ significantly between the groups. Gravidity, parity, and perinatal outcomes were also similar in the two groups.

As expected, serum fasting glucose, insulin, and $\mathrm{HbAlc}$ levels, as well as HOMA-IR scores, were significantly higher in pregnant women with GDM than in controls $(\mathrm{p}=0.009, \mathrm{p}<0.001$, $\mathrm{p}=0.013$, and $\mathrm{p}<0.001$, respectively). Total cholesterol and LDL cholesterol levels were similar in the two groups ( $\mathrm{p}=0.810$ and $p=0.273$, respectively). VLDL cholesterol and triglyceride levels were significantly higher in the GDM group than in the control group (both $\mathrm{p}=0.020$ ). Glucose and lipid metabolism parameters are summarized in Table 2.

Serum betatrophin levels were significantly higher in patients with GDM than in the control group ( $<<0.001$; Figure 1). No significant correlation was evident between betatrophin levels and glucose or lipid metabolism parameters in the control group. However, significant correlations were detected between the betatrophin levels and insulin levels ( $r=0.336$, $\mathrm{p}=0.009$ ), C-peptide levels ( $\mathrm{r}=-0.399, \mathrm{p}=0.002)$, and HOMAIR scores $(r=0.269, p=0.038)$ in the GDM group; they were not correlated with any other glucose or lipid parameter. The results of correlation analyses for the GDM and control groups are

Table 1. Maternal characteristics and birth outcomes of the study and control groups

\begin{tabular}{|c|c|c|c|}
\hline & $\begin{array}{l}\text { Gestational DM } \\
(\mathrm{n}=30)\end{array}$ & Control $(n=30)$ & $\mathrm{p}$ value \\
\hline Age (years)* & $34.50 \pm 5.05$ & $32.93 \pm 5.34$ & $0.248^{t}$ \\
\hline BMI $\left(\mathrm{kg} / \mathrm{m}^{2}\right)^{*}$ & $24.73 \pm 5.21$ & $22.90 \pm 2.26$ & $0.493^{t}$ \\
\hline Gravidity** & $4(2-11)$ & $3(1-7)$ & $0.324 u$ \\
\hline Parity** & $2(1-9)$ & $1(0-5)$ & $0.527 \mathrm{u}$ \\
\hline $\begin{array}{l}\text { Gestational age } \\
\text { at screening } \\
\text { (weeks)** }\end{array}$ & $25.0(24-28)$ & $24.0(24-26)$ & $0.752^{\mathrm{u}}$ \\
\hline $\begin{array}{l}\text { Gestational age at } \\
\text { birth (weeks)* }\end{array}$ & $38.90 \pm 1.86$ & $39.20 \pm 1.10$ & $0.152^{\mathrm{t}}$ \\
\hline $\begin{array}{l}\text { Mode of } \\
\text { delivery } * * *\end{array}$ & - & - & $0.493^{f}$ \\
\hline Vaginal & $9(30)$ & $12(40)$ & - \\
\hline Caesarean section & $21(70)$ & $18(60)$ & - \\
\hline Birthweight (g)* & $3396.00 \pm 590.90$ & $3249.00 \pm 269.12$ & $0.128^{t}$ \\
\hline Sex $* * *$ & - & - & $0.210^{x}$ \\
\hline Male & $12(40)$ & $16(53.3)$ & - \\
\hline Female & $18(60)$ & $14(46.7)$ & - \\
\hline \multicolumn{4}{|c|}{$\begin{array}{l}{ }^{*} \text { Mean } \pm \text { standard deviation, }{ }^{* *} \text { median (range), } * * * n(\%) \text {. } \\
\text { Continuous data are expressed as mean } \pm \text { standard deviation or the median (interquartile } \\
\text { range) and categorical data are expressed as } \mathrm{n}(\%) \text {. The differences among groups were } \\
\text { assessed using the 't-test or "Mann-Whitney U test, as appropriate. Categorical variables } \\
\text { were assessed using the xPearson chi-square test and 'Fisher's exact test, as appropriate. } \\
\text { BMI, body mass index; DM, diabetes mellitus }\end{array}$} \\
\hline
\end{tabular}


summarized in Table 3. Multivariate stepwise linear regression analysis revealed that the insulin levels $(\beta=0.134, p=0.013)$ and HOMA-IR values ( $\beta=0.112, \mathrm{p}=0.017$ ) were independently related factors associated with serum betatrophin levels.

\section{Discussion}

The data presented here demonstrate that serum circulating betatrophin levels were significantly higher among pregnant

Table 2. Carbohydrate and lipid metabolism parameter levels

\begin{tabular}{|c|c|c|c|}
\hline & $\begin{array}{l}\text { Gestational } \\
\text { DM }(n=30)\end{array}$ & $\begin{array}{l}\text { Control } \\
(n=30)\end{array}$ & $\mathrm{p}$ \\
\hline Glucose $(\mathrm{mg} / \mathrm{dL}) *$ & $90.03 \pm 19.89$ & $79.56 \pm 7.54$ & 0.009 \\
\hline $\mathrm{HbAlc}(\%)^{*}$ & $4.93 \pm 0.47$ & $4.63 \pm 0.45$ & 0.013 \\
\hline Insulin $(\mu \mathrm{IU} / \mathrm{mL})^{*}$ & $84.85 \pm 2.89$ & $13.83 \pm 6.69$ & $<0.001$ \\
\hline C-peptide (ng/mL)* & $1.70 \pm 1.18$ & $0.61 \pm 0.33$ & $<0.001$ \\
\hline $\begin{array}{l}\text { Total cholesterol } \\
(\mathrm{mg} / \mathrm{dL})^{*}\end{array}$ & $228.56 \pm 40.40$ & $225.70 \pm 51.14$ & 0.810 \\
\hline $\begin{array}{l}\text { HDL cholesterol } \\
(\mathrm{mg} / \mathrm{dL})^{*}\end{array}$ & $61.96 \pm 15.95$ & $71.00 \pm 17.07$ & 0.039 \\
\hline $\begin{array}{l}\text { LDL cholesterol } \\
(\mathrm{mg} / \mathrm{dL})^{*}\end{array}$ & $140.65 \pm 37.71$ & $129.79 \pm 38.31$ & 0.273 \\
\hline $\begin{array}{l}\text { VLDL cholesterol } \\
(\mathrm{mg} / \mathrm{dL})^{*}\end{array}$ & $45.33 \pm 16.22$ & $36.33 \pm 12.60$ & 0.020 \\
\hline Triglycerides (mg/dL)* & $226.56 \pm 81.17$ & $181.60 \pm 62.92$ & 0.020 \\
\hline HOMA-IR score* & $3.03 \pm 1.63$ & $0.95 \pm 0.58$ & $<0.001$ \\
\hline
\end{tabular}

*Mean \pm standard deviation.

Student's t-test was used to compare biochemical parameters between the control and study groups. Significant $\mathrm{p}$ values are shown in bold.

HbAlc: Hemoglobin Alc, HDL: High-density-lipoprotein, LDL: Low-density-lipoprotein, VLDL: Very-low-density-lipoprotein, HOMA-IR: Homeostatic model of assessment of insulin resistance, DM: Diabetes mellitus

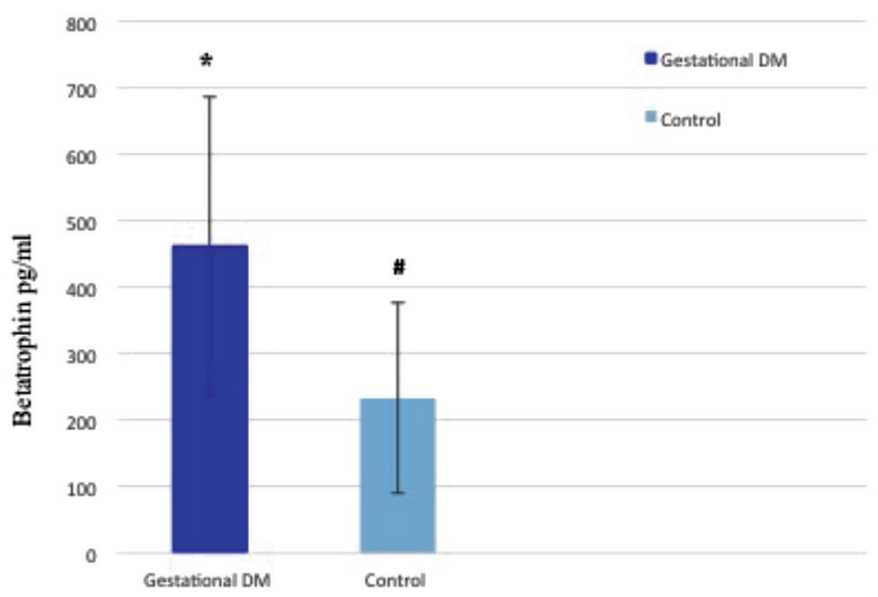

Figure 1. Differences in betatrophin levels between groups. Values are means \pm standard deviations $(\mathrm{pg} / \mathrm{mL}) .{ }^{*}$ and \# indicate significant differences $(\mathrm{p}<0.001)$. Gestational diabetes mellitus: 463.19 \pm 224.64 , control: $233.13 \pm 143.63$, $p<0.001$.

DM: Diabetes mellitus women with GDM than among normoglycemic (control) pregnant women. In recent years, changes in various hepatocyte- and adipocyte-derived factors, such as adiponectin, resistin, leptin, and adipocyte fatty acid-binding protein, have been reported as mediators for the regulation of pregestational $\mathrm{DM}$ and $\mathrm{GDM}^{(15)}$. In addition, betatrophin has been identified as a new adipokine/hepatokine, and has been claimed to have important roles in promoting $\beta$-cell proliferation and $\beta$-cell mass expansion in animal and human studies ${ }^{(16,17)}$. Sun et al. ${ }^{(18)}$ demonstrated that the transplantation of betatrophinexpressing adipose-derived mesenchymal stem cells induced $\beta$-cell proliferation in mice with streptozotocin (STZ)-induced diabetes $^{(18)}$. They showed that betatrophin overexpression induced pancreatic islet proliferation, $\beta$-cell-specific transcription factor expression, and insulin production by islet cells under glucose stimulation. In contrast, Gusarova et al. ${ }^{(19)}$ failed to show growth of beta cells in mice in response to targeted ANGPTL8 overexpression. Jiao et al. ${ }^{(20)}$ demonstrated that betatrophin stimulated $\beta$-cell replication in an experimental S961-induced insulin resistance model in mice, but they did not increase human $\beta$-cell DNA replication in the transplanted setting ${ }^{(20)}$. These inconsistent results of increased betatrophin may be due to the experimental models used (i.e., STZ-induced diabetes vs. S961-induced insulin resistance). In particular, the S961-induced insulin resistance model may be effective for shorter-duration experiments. Moreover, the proliferative

Table 3. Correlations between the betatrophin level and clinical and biochemical parameters in the GDM and control groups in weeks 24-28 of pregnancy

\begin{tabular}{lllll} 
Variable & \multicolumn{2}{c}{ Control group } & \multicolumn{2}{c}{ GDM group } \\
& r & p & r & p \\
\hline Age & -0.251 & 0.182 & -0.073 & 0.702 \\
\hline BMI at weeks 24-28 & 0.159 & 0.164 & 0.140 & 0.194 \\
\hline Fasting glucose level & -0.157 & 0.408 & -0.303 & 0.104 \\
\hline HbAlC level & 0.031 & 0.869 & -0.056 & 0.770 \\
\hline Insulin level & 0.176 & 0.352 & $0.336 *$ & 0.009 \\
\hline C-peptide level & 0.279 & 0.059 & $-0.399 *$ & 0.002 \\
\hline HOMA-IR score & 0.119 & 0.531 & $0.269 *$ & 0.038 \\
\hline Triglyceride level & 0.194 & 0.303 & -0.063 & 0.742 \\
\hline Total cholesterol level & -0.124 & 0.514 & -0.111 & 0.561 \\
\hline HDL cholesterol level & 0.094 & 0.622 & -0.149 & 0.433 \\
\hline LDL cholesterol level & -0.109 & 0.566 & -0.213 & 0.259 \\
\hline VLDL cholesterol level & 0.194 & 0.305 & -0.063 & 0.742 \\
\hline
\end{tabular}

* Significant $(\mathrm{p}<0.05)$. Correlation analyses were performed by using non-parametric Spearman's correlation test. Significant p values are shown in bold.

BMI: Body mass index, HbAlc: glycated hemoglobulin AlC, HDL: High-densitylipoprotein, LDL: Low-density-lipoprotein, VLDL: Very-low-density-lipoprotein, HOMA-IR: Homeostatic model of assessment of insulin resistance, GDM: Gestational diabetes mellitus. 
potential of pancreatic islet cells can vary among mouse age groups, which may have biased the outcomes. Although the mechanism underlying the effect of betatrophin on glucose homeostasis has been attributed to increased $\beta$-cell proliferation, the precise impact of betatrophin on insulin secretion remains unclear, and further studies are needed to elucidate the exact mechanism.

In view of the frequency of GDM, several animal and human studies have been conducted to identify potential pathophysiological factors for insulin resistance in women with GDM. As a novel biomarker of glucose and lipid metabolism, betatrophin has been suggested to have a regulatory role in insulin resistance in patients with $\mathrm{GDM}^{(21)}$. The results of the present study also reveal that insulin levels and HOMA-IR scores are associated independently with serum betatrophin levels. Chen et al. ${ }^{(22)}$ reported a significant increase in the betatrophin level in patients with type $2 \mathrm{DM}$, and showed significant correlations between the betatrophin level and insulin resistance indices, including the HOMA-IR score. Kong et al. ${ }^{(23)}$ conducted a meta-analysis to evaluate the association between circulating betatrophin levels and GDM, and indicated that circulating betatrophin was evident in patients with GDM, especially in those with BMIs $\geq 28 \mathrm{~kg} / \mathrm{m}^{2}$ during the third trimester. They proposed that a higher tendency for insulin resistance in the third trimester of pregnancy and in obese patients may have contributed to these results, obtained from a subgroup analysis. Wawrusiewicz-Kurylonek et al. ${ }^{(24)}$ showed increased maternal circulating betatrophin levels in patients with GDM, and the levels were about five times higher in cord blood than in maternal serum. They noted a negative correlation between maternal betatrophin and serum C-peptide concentrations, and suggested that decreased insulin secretion capability altered the betatrophin level.

Lipid metabolism significantly changes through pregnancy, due mainly to an increase in adipose tissue followed by increased lipolysis and hypercholesterolemia ${ }^{(25)}$. Changes in oestrogen and progesterone have been proposed to contribute significantly to this physiologic hyperlipidaemia. However, the association between increased adiposity and circulating betatrophin in maternal serum has not been clearly defined ${ }^{(26)}$. In this study, we observed no correlation between the serum betatrophin levels and lipid parameters in the GDM or control group. Similarly, Erol et al. ${ }^{(27)}$ evaluated circulating betatrophin levels and metabolic parameters in women with GDM and found no correlation between betatrophin levels and lipid parameters, including triglyceride, total cholesterol, LDL cholesterol, and HDL cholesterol levels. By contrast, Fenzl et al. ${ }^{(28)}$ demonstrated a significant association between betatrophin levels and atherogenic lipid profiles in patients with morbid obesity or type $2 \mathrm{DM}$. These conflicting results may be attributed to differences in study design, sample size, or the immunoassay kits used for laboratory assessment. Further studies with larger samples are needed before more definitive conclusions can be made.

\section{Study Limitations}

The current study has several limitations, such as the examination of a small sample from a single centre. However, the number of patients participating in the study was sufficient to analyse the serum betatrophin level and metabolic parameters. The change in betatrophin during the course of pregnancy was not determined because we were only able to analyse secondtrimester serum betatrophin levels. The main strength of the study was the prospective cohort design with strict inclusion and exclusion criteria, which minimised the effects of potential confounding factors. A further strength was that the study and control groups were well matched in terms of baseline characteristics.

\section{Conclusion}

This study demonstrated that serum betatrophin levels were significantly higher in pregnant women with GDM than in normoglycemic pregnant women. The level of betatrophin was correlated significantly with insulin resistance parameters, which is a key feature of GDM pathophysiology. These findings may help to clarify the pathophysiology of GDM and may be useful for the prediction of GDM development during the second trimester.

\section{Acknowledgments}

This study was supported by the Research Fund of University (project no: TF.16.08).

\section{Ethics}

Ethics Committee Approval: This study was approved by the Local Ethics Committee of Frrat University, and informed consent was obtained from all participants in accordance with the principles of the Declaration of Helsinki (approval no: 97132852/050.01.04)

Informed Consent: Informed consent was obtained from all participants.

Peer-review: Externally peer-reviewed.

\section{Authorship Contributions}

Surgical and Medical Practices: E.Ç.K., Concept: H.B., Design: E.C..K., Data Collection or Processing: R.M., A.A., Analysis or Interpretation: M.F.G., F.G.B., Literature Search: H.B., E.C..K., Writing: F.G.B., R.M., M.F.G., H.B., E.C.K., A.A.

Conflict of Interest: The authors declare no conflict of interest regarding the publication of this article.

Financial Disclosure: The authors declared that this study received no financial support.

\section{References}

1. American Diabetes Association. Classification and diagnosis of diabetes. Diabetes Care, 2015; 38 Suppl: S8-S16.

2. Jiwani A, Marseille E, Lohse N, Damm P, Hod M, Kahn JG. Gestational diabetes mellitus: results from a survey of country prevalence and practices. J Matern Fetal Neonatal Med. 2012;25:600-10.

3. Feldman RK, Tieu RS, Yasumura L. Gestational diabetes screening: the International Association of the Diabetes and Pregnancy Study 
Groups compared with Carpenter-Coustan Screening. Obstet Gynecol 2016; 127:10-7.

4. Negrato CA, Mattar R, Gomes MB. Adverse pregnancy outcomes in women with diabetes. Diabetol Metab Syndr 2012;4:41.

5. ACOG Practice Bulletin No. 190: Gestational Diabetes Mellitus. Obstet Gynecol. 2018;131(2):e49-e64.

6. Ren G, Kim JY, Smas CM. Identification of RIFL, a novel adipocyteenriched insulin target gene with a role in lipid metabolism. Am J Physiol Endocrinol Metab 2012;303:E334-E351.

7. Zhang R. Lipasin, a novel nutritionally-regulated liver-enriched factor that regulates serum triglyceride levels. Biochem Biophys Res Commun 2012;424:786-92.

8. Fu Z, Berhane F, Fite A, Seyoum B, Abou-Samra AB, Zhang R. Elevated circulating lipasin/betatrophin in human type 2 diabetes and obesity. Sci Rep 2014; 23:5013.

9. Quagliarini F, Wang Y, Kozlitina J, Grishin NV, Hyde R, Boerwinkle $\mathrm{E}$, et al. Atypical angiopoietin-like protein that regulates ANGPTL3. Proc Natl Acad Sci U S A 2012;109:19751-6.

10. Hu H, Sun W, Yu S, Hong X, Qian W, Tang B, et al. Increased circulating levels of betatrophin in newly diagnosed type 2 diabetic patients. Diabetes Care 2014;37: 2718-22.

11. Gómez-Ambrosi J, Pascual E, Catalán V, Rodríguez A, Ramírez B, Silva C, et al. Circulating betatrophin concentrations are decreased in human obesity and type 2 diabetes. J Clin Endocrinol Metab 2014;99:E2004-E2009.

12. Metzger BE, Gabbe SG, Persson B, Buchanan TA, Catalano PA, Damm $P$, et al. International association of diabetes and pregnancy study groups recommendations on the diagnosis and classification of hyperglycemia in pregnancy. Diabetes Care 2010;33:676-82.

13. Matthews DR, Hosker JP, Rudenski AS, Naylor BA, Treacher DF, Turner RC, et al. Homeostasis model assessment: insulin resistance and beta-cell function from fasting plasma glucose and insulin concentrations in man. Diabetologia. 1985;28:412-9.

14. Trebotic LK, Klimek P, Thomas A, Fenzl A, Leitner K, Springer S, et al. Circulating betatrophin is strongly increased in pregnancy and gestational diabetes mellitus. PLoS One 2015;10:e0136701.

15. Miehle K, Stepan H, Fasshauer M. Leptin, adiponectin and other adipokines in gestational diabetes mellitus and pre-eclampsia. Clin Endocrinol (Oxf) 2012;76:2-11.

16. Yi P, Park JS, Melton DA. Betatrophin: a hormone that controls pancreatic $\beta$ cell proliferation. Cell 2013;153:747-58.
17. Espes D, Lau J, Carlsson PO. Increased circulating levels of betatrophin in individuals with long-standing type 1 diabetes. Diabetologia 2014;57:50-3.

18. Sun LL, Liu TJ, Li L, Tang W, Zou JJ, Chen XF, et al. Transplantation of betatrophin-expressing adipose-derived mesenchymal stem cells induces $\beta$-cell proliferation in diabetic mice. Int J Mol Med. 2017;39:936-48.

19. Gusarova V, Alexa CA, Na E, Stevis PE, Xin Y, Bonner-Weir S, et al. ANGPTL8/betatrophin does not control pancreatic beta cell expansion. Cell 2014;159:691-6.

20. Jiao Y, Le Lay J, Yu M, Naji A, Kaestner KH. Elevated mouse hepatic betatrophin expression does not increase human $\beta$-cell replication in the transplant setting. Diabetes 2014;63:1283-8.

21. Xu J, Lin Y, Zhou H, Zhao L, Xiang G. The correlation between circulating betatrophin and insulin resistance in general population: a meta-analysis. Horm Metab Res 2017;49:760-71.

22. Chen X, Lu P, He W, Zhang J, Liu L, Yang Y, et al. Circulating betatrophin levels are increased in patients with type 2 diabetes and associated with insulin resistance. J Clin Endocrinol Metab 2015;100:96-100.

23. Kong FJ, Ma LL, Li G, Chen YX, Zhou JQ. Circulating betatrophin levels and gestational diabetes mellitus: a systematic review and meta-analysis. PLoS One 2017;12:e0169941.

24. Wawrusiewicz-Kurylonek N, Telejko B, Kuzmicki M, Sobota A, Lipinska D, Pliszka J, et al. Increased maternal and cord blood betatrophin in gestational diabetes. PLoS One 2015;10:e0131171.

25. Herrera E, Ortega-Senovilla H. Maternal lipid metabolism during normal pregnancy and its implications to fetal development. Clin Lipidol 2010;5:899-911.

26. Mankuta D, Elami-Suzin M, Elhayani A, Vinker S. Lipid profile in consecutive pregnancies. Lipids Health Dis 2010;9:58.

27. Erol O, Ellidağ HY, Ayık H, Özel MK, Derbent AU, Yılmaz N. Evaluation of circulating betatrophin levels in gestational diabetes mellitus. Gynecol Endocrinol 2015;31:652-6.

28. Fenzl A, Itariu BK, Kosi L, Fritzer-Szekeres M, Kautzky-Willer A, Stulnig TM, et al. Circulating betatrophin correlates with atherogenic lipid profiles but not with glucose and insulin levels in insulin-resistant individuals. Diabetologia 2014;57:1204-8. 